\title{
Public Participation in 2018 Pemalang Simultaneous Village Head Election by e-Voting System
}

\author{
Neny Marlina ${ }^{1}$, Lusia Astrika ${ }^{2}$ \\ \{nenymarlina@live.undip.ac.id ${ }^{1}$ \} \\ Universitas Diponegoro, Indonesia ${ }^{1,2}$
}

\begin{abstract}
The purpose of the study is to analyze the efforts in increasing public participation in the 2018 Pemalang simultaneous village head elections, which was conducted by the e-voting mechanism. The implementation of village head election by the e-voting system in Pemalang regency was the first implementation of using fingerprints. The election through the e-voting system is a new mechanism for the implementation in the village head election. Moreover, when the rural location comes into consideration, the system is interesting to be seen as a form of innovation as well as a challenge for the government to increase public participation. The research employs the theory of public participation and political socialization together with qualitative research method. This research exhibits that the success in increasing public participation in the simultaneous village head election in Pemalang regency in 2018, was through two means carried out by the government, namely political socialization which was carried out in stages, starting from the regency level down to the village level. The impediment in the shifting of the village head election system from a manual system to the e-voting system turned out providing a different picture for the 172 villages that were implementing the system. The implementation of simultaneous village head election through e-voting system-generated different responses in the community due to the different village conditions. In addition, there was also institutional strengthening in the various related institutions, starting from the regency level down to the village level, which supports the implementation of the 2018 Pemalang simultaneous village head election.
\end{abstract}

Keywords: Political Participation, Socialization, E-Voting

\section{Introduction}

A village is a unit of law, where people live there with their own government. According to Bintarto [1], the village is either the embodiment or the unity of the geography, social, economic, political and cultural in which in that place (an area), in relation and its influence reciprocally with other areas. In the village development, the main goal is to do the development of the village people. Nevertheless, the two understandings do not need to be separated or distinguished by absolute because the essence of the development of the village has become one method and is a unity, consisting of the components of each other interrelated with. As the evidence, it can be concluded that a country will remain to exist, as long as the village, nagari, marga existed, as long as the state is able to unite itself with the village, nagari, and marga [2]. Village People Development (Indonesian: Pembangunan Masyarakat Desa) is one of the important and decisive components. Therefore, this component must be fully constructed, both the physical environment and the social environment. This makes the 
development of the village becomes complex because it involves the people as a development center. The actors in developing the village are also determined by the village government in taking the policy for village development. The village government consisting of the village government and BPD (Indonesian: Badan Permusyawaratan Desa; English: Village Consultative Body) must play an active role in involving the people to jointly achieve village progress. The village government has a very influential role in the efforts of creating a climate that encourages the growth of initiatives and autonomy in rural areas, which are conducted through messages of development, briefing to the people to participate in the development and distribution of people's aspirations. The development of the village is not only measured by development results but also must be seen from the process in the development. The importance of people's participation also determines the success of village development achievement.

Village people participation is realized in the form of briefing and utilization of power and funds in the people to increase development activities in rural areas, hence, that the success of development in society is not always determined by the availability of financial resources and financial management but more influenced by the people's participation and response to development or can be referred to as the people. The achievement of the success of people participating in the development requires local leadership that is capable, authoritative and accepted by society. One of the fundamental issues in the process of organizing a village government is how to build or create a governance mechanism that can carry out its mission in realizing a prosperous society in fairness. The government must implement development based on people's aspirations, and provide the best public services.

The head of the village is the head of the village government organization that is strategically positioned and has broad responsibility. The responsibilities include the work of a separate job and divided into government agency officials based on the principle of deconcentration and decentralization, while the village responsibilities on the affairs of service duties are centered on the village head. Responsibilities of the duties of the work can be implemented by the head of the village or through others. It means to foster public participation, a formal leader is needed, i.e. village head, to encourage and motivate society to participate in development. The head of the village should be able to act as motivator, communicator and able to build people organization to increase people's participation in the development process [3]. Therefore, the village head is the first step to determine the right leader in the process of village development. The issuance of law number 6 of 2014 concerning the village provides different ordinances in the implementation of village head elections [4]. If the election of village heads is carried out with different time periods among the villages, now the process of electing the village head is held simultaneously in one regency.

The Election of Village Heads (Indonesian: Pemilihan Kepala Desa, Pilkades) simultaneously became an interesting phenomenon in rural political studies because the party of democracy in the village level becomes more fervent when it is held simultaneously. One of the interesting to be observed is the implementation of simultaneous Pilkades that is held in the regency of Pemalang in 2018. The implementation of Pilkades by using E-Voting system in Pemalang Regency, is the third activity in 2018, after Sidoarjo regency and the regencies in Jambi. However, the implementation of Pilkades by the E-voting system in Pemalang regency is the first implementation that using fingerprints [5]. The election of village heads (Pilkades) was done simultaneously but in phases in 172 villages. The election of village heads (Pilkades) held simultaneously from 2 September to 4 November 2018 through this e-voting system, which is considered as more efficient and easier to do for all levels of society that 
already have an Electronic Residential Card (Indonesian: Kartu Tanda Penduduk Elektronik, e-KTP) [6]. Through this E-voting system, it is a new mechanism in the implementation of Pilkades, moreover, if conditions in the countryside come to consideration, this system is interesting to be seen as a form of innovation. According to the regent of Pemalang, Junaedi the citizen participation rate in e-voting Pilkades, and e-verification by using the fingerprint phase II in the regency of Pemalang reached $70 \%$ higher when compared to the participation of the people at the time of the presidential election, Pileg (Indonesian: Pemilihan Legeslatif; English: Legislative Election), Pilgub (Indonesian: Pemilihan Gubernur; English: Governor Election), and Pilbup (Indonesian: Pemilihan Bupati; English: Regent Election) [7]. Therefore, this research is interested in knowing the efforts to improve the people's political participation in the election of village heads simultaneously 2018 in Pemalang regency through the system of e-voting and know the supporting factors and an obstacle in such efforts.

\section{Research methods}

This research is located in the regency Pemalang province of Central Java. The method used in this study is a qualitative research method with a case study approach [8]. The selection of informants was conducted by purposive sampling. The data used in this study are primary data and secondary data. Primary data is derived from in-depth interviews with informant whereas secondary data is obtained through related supporting literature. This study also added descriptive quantitative methods as supporting qualitative data [9] in order to see people's perceptions in the e-voting Pilkades by taking a sample of 100 respondents.

\section{Research and Discussion}

\subsection{Concept of Political participation and socialization}

Political participation in politics has a diverse understanding. There are some experts who express their opinion on political participation. Political participation is the activity of a person or group of people to participate actively in political life, namely by means of choosing the leadership of the state and directly or indirectly, affecting government policy [10]. According to Ramlan Surbakti, the one that is referred by political participation is the participation of ordinary citizens in determining the decisions that concern or influence his life [11]. Herbert McClosky a figure of participatory matter, argued that political participation is the voluntary activities of the citizens through which they take part in the process of selecting the ruler, and directly or indirectly, in the general policy formation process [10]. In relation to the developing countries, Hutington and Nelson gave a wider interpretation by explicitly incorporating illegal and violent acts. Political participation is the activity of citizens acting as private, intended to influence decision-making by the government. Participation can be individual or collective, organized or spontaneous, steady or sporadic, in peace or by force, legal or illegal, effective or ineffective. Miriam Budiarjo generally interpreted political participation as a person or group of people to actively participate in political life, namely by selecting the head of the state directly or indirectly affecting the government policy (public policy) [12]. Finally, according to Keith Faulks political participation is the active 
involvement of individuals as well as groups in government processes impacting their lives. This includes involvement in decision-making and opposition action, which is important participation is an active process. According to Surbakti political participation is divided into two, namely active participation and passive participation. Active participation is to propose a general policy, propose a different general policy alternative to government-made policies, submit criticism and improvement to straighten policies, pay taxes and choose Government leaders. In contrast, activities that belong to the category of passive participation are activities that obey the government, accept, and exercise alone every decision of the government [11]. Meanwhile, Milbart and Goel distinguish participation in several categories. First, apathy. That is people who do not participate and withdraw from the political process. Second, spectator. That is the person who at least once voted in the elections. Thirdly, gladiators. This means that those who are actively involved in the political process, namely communicators, specialists conduct face-to-face contact, party activists and campaign workers, and community activists [13]. Participation can be individual or collective, organized or spontaneous, steady or sporadic, in peace or by force, legal or illegal, effective or ineffective).

\subsection{Socialization: From Manual to E-Voting}

The election of village heads by using the e-voting system in Regency of Pemalang in 2018 is not the first time. In 2016 Pemalang Regency has been conducting electoral village through e-voting system for 11 villages. The year 2016 is an important time to transition into changing the selection mechanism in a new way. 11 villages by using the e-voting system provided several advantages compared to the conventional way of selecting the village head in 2012. One of the example is that there is a lot of vote difference occurs with the conventional elections at the phase of the vote counting, giving rise to the lengthy calculation because it has to be counted repeatedly, which can be solved by using e-voting system because the number of votes is already stored in the computer, hence it does not take a long time in the calculation. Starting from this, the election of village head simultaneously in Pemalang regency in 2018 prefer to use a new mechanism that is with the e-voting system. Different from 2016, the condition of implementing the village head election mechanism simultaneously by using evoting system in 2018 has many challenges because the number of villages is as many as 172 villages. Therefore, the election of village heads simultaneously in 2018 was momentum in seeing celebrations of democracy at the village level with the change of mechanisms from conventional to e-voting.

The most crucial thing to challenge the government of Pemalang is to provide socialization to the public and the lack of mastery of the technology to participate in the election of village heads by using the new system. So far, the election of the village head is one of the means of distribution of village people that is commonly understood as a celebration of democracy in the village because at this time the vote of the village people really determines in voting for the leader for village progress. Therefore, the system changes from conventional to e-voting with 172 villages simultaneously conducting the election of village heads should not eliminate the meaning of the village's celebrations of democracy by still involving the entire recorded society as the permanent voter to participate. Thus, the election of village head simultaneously by e-voting system needs to involve many related agencies for the success and the smooth implementation. The deployed socialization includes two ways, which the first one was by conducting a team that aims to ensure the use of the e-voting tools correctly and the second was to conduct socialization from the regency level up to the village committee. 
Socialization was first made to the technical committee in charge of maintaining the smooth implementation of e-voting related to the tools that are used. The tool used in this evoting was a tool issued by BPPT Jakarta (Indonesian: Badan Pengkajian dan Penerapan Teknologi; English: Agency for Technology Assessment and Application) which is a supervised PT. Inti in Bandung. This socialization was carried out to inform that the implementation of Pilkades with e-voting system is a legal activity and tools used have been passed through the test process in the Constitutional Court (Indonesian: Mahkamah Konstitusi). This was also enforced by the issuance of Pemalang District Regulation Number 6 of 2017 concerning Amendment to Regional Regulation number 1/2015 concerning Procedures for Election, Appointment, and Dismissal of Village Heads, Regent Regulation, and provisions of the Ministry of Internal Affairs. The regulation - among others - was delivered to each village through the Decree of Pemalang Regent Number 141.1/386/2018 dated 7 May Concerning the Implementation of the Simultaneous Village Head Election in Pemalang Regency. The establishment of this technical team was collaborated directly with BPPT to form two teams, namely the Main Technical Team (Indonesian: Tim Teknis Utama, TTU) and the Field Technical Team (Indonesian: Tim Teknis Lapangan, TTL). TTU consisted of 10 people and TTL consisted of 40 people recruited from various agencies. TTU was specially recruited by BPPT and specially trained by BPPT so that its position is higher than TTL. However, TTL was also through the process of recruitment derived from 20 OPD (regional device organization) and trained to obtain competency certification. TTL acted as supervision or monitoring the implementation of e-voting in each village while the village field technical team was trained by the TTL and recruited by the village head election committee in each village. The total for the socialization regarding the use of certified e-voting equipment was 50 people. This team assisted the people at the village level to conduct election simulations with the e-voting tools. This was done to preserve the public voters' trust in the tools used in the election of village heads with the e-voting system.

The second socialization was carried out gradually from the regency government to the village level. Socialization that was conducted at the regency level was in the form of cooperation with the related service to help each other in the implementation of e-voting such as Sekda (Regional Secretariat), Dinpermades, Diskominfo (Department of Communication and Information), and Disdukcapil (Department of Population and Civil registration) and Head of Education Office if necessary to issue a budget. The socialization was done in a period of two and a half months starting around May. The socialization of the village began with the BPD (Village Consultative Agency), the Pilkades committee, and the supervisory team. In the delivery of socialization, it was explained that the phases which were conducted electronically included the selection stage, verification phase, calculation stage and the stage of recapitulation. The socialization that was done on the BPD also provides the simulation of how to use the e-voting tool for village head election, through this simulation that each BPD will deliver back to the village. The first socialization carried out at the village organizers, in then the second socialization is done in each village but at the time of the socialization, it was not all village people can be present to follow the simulation so the village actors were needed to inform the way of voting with e-voting to the absent people. The BPD is also tasked to establish and appoint a village head election committee organized through village deliberations as well as providing socialization of e-voting to the elected Pilkades committee. After the organizers of the village-level Pilkades were elected, the village committee served together with the BPD to socialize Pikades by e-voting in the village. Village Committee performed an innovation to convey the socialization of e-voting, which was by making a video tutorial of the election using local language which is used daily so that it is easy to understand 
and choose the appropriate time for the people. Socialization activities at the village level adapt to the condition of each village. The creativity of each committee and organizer at the village level finally helped the Pemalang Regency government through Dinpermades to conduct socialization. The village committee together with BPD was also tasked to record the number of DPT (Indonesian: Daftar Pemilih Tetap; English: Fixed Voter Lists) in their respective villages. If the DPT process is completed, then the registration committee at the village level was delivered to the Secretariat and the finalization of DPT is announced in each village.

Socialization was conducted in stages, providing freedom for the village to socialize according to local wisdom and customs of local villagers. This makes socialization felt more touching for the people because it was more flexible to adjust the local time. Socialization in this way did take longer than the socialization for the election of village heads with conventional mechanisms. However, this was done in order to make the implementation of Pilkades by e-voting systems not to soften the meaning of the celebration of democracy by the decrease of public interest in electing village heads. The granting of authority to the village to provide socialization to the people is also one of the effective ways to touch the people that were absent when the simulation of e-voting equipment was performed.

\subsection{Participation}

The Pilkades Pemalang Regency of 2018 which is carried out simultaneously by using the e-voting system was implemented in stages. This stage is divided into 10 stages, in one stage carried out for 16 to 18 villages. The implementation of the Pilkades is executed every Sunday starting with the first stage that was held on 2 September 2018 until the tenth stage of 4 November 2018. In the implementation of the first phase, the percentage of voters who participated in the overall vote in 18 villages was about $70.5 \%$. This percentage of participation went through dynamic experienced in its implementation in the next 9 stages. From 100 respondents, 41 of them stated that the reason for participating in the e-voting Pilkades of 2018 was to choose the head of the village that brought the progress and other 40 reasoned they were following Pilkades as a form of obligation as a citizen. The high participation also took place in the 4th phase which was held on 23 September 2018 which was around $87 \%$. The lowest participation was about $65 \%$, which was obtained during the implementation in phase 10 , which was the last phase of the implementation of Pilkades conducted on November 4, 2018. The average voter participation from the whole stages was $75 \%$ of the 172 villages that organized the Pilkades. This suggests that using the e-voting system did not degrade people's interest in participating to choose a village head from the available candidates.

Pilkades through the e-voting system did not change the meaning of celebrations of democracy as previously concerned. The data that were obtained through quantitative analysis tests of 100 respondents showed that 83 respondents stated that the vote counting was running smoothly and that the voting stages were faster than conventional systems. The recognition of Dinpermades also emphasizes that people's participation by e-voting is more than the conventional system. Another reason that made people come to choose in the Pilkades in addition to choosing a village head was a curiosity about the e-voting system. The simultaneous mechanism of Pilkades with e-voting was also able to reduce some of the fraud that usually occurs in conventional mechanisms such as the number of voters that do not correspond to the amount of DPT. The socialization that had been done in stages and reciprocal communication between the village committee and the regency government made 
the DPT problem to be not a problem because it was done with many verifications to determine the final amount of DPT. People who are not on the DPT list cannot use the vote because the e-KTP was not readable by the KTP Reader tool so that the number of voters is surely to match the DPT that had been inside the tool. It avoids double voters and so on. Speed and accuracy in the vote-counting process also made the people did not have to wait for long for the result of the Pilkades. This condition is certainly much more effective and efficient than conventional system.

Village people's involvement was not only seen from their participation in the use of suffrage but also a willingness to use village funds to purchase a set of e-voting tools. A complete set of e-voting tools consists of one all in one PC with touch screen, 2 laptop units (1 is used for DPT verification and 1 more for smartcard rechargeable generator tokens), 1 unit of ID card reader and printer. A set of e-voting tools and applications purchased by each village using village funds worth Rp. 49.7 million. The village's willingness to buy a set of evoting tools shows that the villagers welcomed the 2018 Pilkades through e-voting positively. Once the e-voting tool has been used, this tool will be utilized by the village as supporting technology for the independent village. Therefore, the purchase of this tool is not only used for one activity only.

\section{Conclusion}

Pemalang District Pilkades 2018 was conducted simultaneously in 172 villages using the e-voting system that has two socialization strategies to increase community participation. The first was by doing cooperation with various related agencies, especially in the establishment of the technical team to support the smooth use of tools in the field. This effort was undertaken to maintain public trust in the tools as well as e-voting officers. The second effort is carried out by the socialization in stages through providing simulation as well as the legal basis to the BPD, the Village-level Pilkades Committee and Supervisory Committee. Through this effort, the village committee felt involved in the activities of the celebrations of democracy that were held simultaneously so that this socialization was also done flexibly in accordance with the available time, language and customs that apply in each village. As a result, people's participation to choose from 172 villages reached $75 \%$ which means that this new mechanism does not soften people's intentions to come and choose a leader for his village progress. This shows that the change in the mechanism of the village head does not change the meaning of democracy and the celebrations of democracy at the village level. Additionally, the village head from the Pilkades result by the e-voting system was appointed in three waves namely 1 December 2018, 9 January 2019 and 19 January 2019.

\section{References}

[1] R. Bintarto, Interaksi desa-kota dan permasalahannya. Ghalia Indonesia, 1983.

[2] Nasroen, Daerah Otonomi Tingkat Terbawah. Jakarta: Beringin Trading Company, 1995.

[3] T. Ardilah, M. Makmur, and I. Hanafi, "Upaya Kepala Desa Untuk Meningkatkan Partisipasi Masyarakat Dalam Pembangunan Desa (Studi di Desa Bareng Kecamatan Bareng Kabupaten Jombang)," J. Adm. Publik, vol. 2, no. 1, pp. 71-77.

[4] Law No.6 of 2014 concerning Villages, vol. 6. 2014. .

[5] "E-Voting Pilkades Di Pemalang Yang Pertama Gunakan Sidik Jari." [Online]. Available: 
https://jatengprov.go.id/beritadaerah/e-voting-pilkades-di-pemalang-yang-pertama-gunakansidik-jari/. [Accessed: 27-Feb-2019].

[6] "Pertama di Indonesia, 83 Kades Hasil E-Voting di Pemalang Dilantik," iNews Portal. [Online]. Available: https://www.inews.id/daerah/jateng/pertama-di-indonesia-83-kades-hasil-e-votingdi-pemalang-dilantik. [Accessed: 27-Feb-2019].

[7] D. O. Sisi, "Di Pemalang, Partisipasi Pilkades E -Voting Tahap II Capai 70\%." [Online]. Available: https://duasisinews.com/di-pemalang-partisipasi-pilkades-e-voting-tahap-ii-capai70/. [Accessed: 27-Feb-2019].

[8] H. Sutopo, Pengantar Kualitatif dan Dasar-Dasar Teoritis. Surakarta: Pusat penelitian UNS, 1998.

[9] Sugiyono, Metode Penelitian Kuantitatif, Kualitatif dan R\&D. Penerbit Alfabeta Bandung, 2010.

[10] M. Budiardjo, "Dasar-dasar ilmu politik, Pt," Gramedia Pustaka Utama, Jakarta, 2008.

[11] R. Surbakti, "Memahami Ilmu Politik, Jakarta," PT Gramedia Widiasarana Indones., 2010.

[12] M. Budiardjo, Partisipasi dan Partai Politik. Jakarta: Gramedia Pustaka Utama, 1982.

[13] Cholisin, Dasar-dasar Ilmu Politik. Yogyakarta: UNY Press, 2007. 